\title{
Infant and young child feeding practices among marginalized populations of Odisha, state in India
}

\author{
Sonali Kar*1 ${ }^{*}$, Sourav Bhattacharjee ${ }^{2}$, PC Samantaray ${ }^{1}$, Seba Biswal ${ }^{1}$ \\ ${ }^{1}$ Community Medicine, KIMS, India \\ ${ }^{2}$ UNICEF, Bhubaneswar, India
}

Received: July 23, 2015

DOI: $10.5430 /$ jer.v2n1p39

Accepted: September 17, $2015 \quad$ Online Published: September 30, 2015

URL: http://dx.doi.org/10.5430/jer.v2n1p39

\begin{abstract}
A global strategy for Infant and Young Child Feeding (IYCF) was issued jointly by the World Health Organization (WHO) and the United Nations Children's Fund (UNICEF) in 2002, to reverse the disturbing trends in infant and young child feeding practices. This stands out as an extremely cost-effective and extremely advantageous method to bring down the infant and child mortality and morbidity especially in developing countries like India.

Odisha, one of the states in India, records just 50\% of exclusive breast feeding practice as reported in National Family Health Survey-3 (2005-6) and also accounts for one of the highest Infant Mortality Rates in the country. Hence the current study was planned jointly by the Nutrition wing of UNICEF and Odisha Voluntary Health Association (OVHA), a Nongovernmental Organization which works for health programs in the state. A baseline study to assess Infant Feeding Practices thus was planned for 7 districts of the state and sampled so as to adequately represent the marginalized population of the state. A detailed questionnaire with information on sociodemographic parameters of the study population and questions that elicited information on the infant and child feeding practices was designed and pretested in a sample population and a team of supervisors and data collectors were trained for the purpose.
\end{abstract}

The study revealed district level data on the infant young child feeding practices in the state. Exclusive Breast Feeding (EBF) was calculated as $48 \%$ and early initiation of breast feeding was nearly $46 \%$. The feeding indicators calculated for 6-23 months age group were of greater concern as minimum dietary diversity is reported $27.4 \%$ and minimum meal frequency is $29 \%$. In spite of the provision of iron syrup and iron folic acid tablets under the flagship program of the country, that is, National Rural Health Mission, for 6-59 months children, the consumption of iron fortified foods is reported as only $6.8 \%$. This could be the cause of high level of morbidity reported in under five in the state.

The data was presented to the state program managers inorder to prioritize the problem areas and take requisite steps at the district level to improve the IYCF indicators in their respective states.

Key Words: Infant and Young Child Feeding, Exclusive Breast Feeding, Optional breast feeding indicators, Marginalized population

${ }^{*}$ Correspondence: Sonali Kar, Project Coordinator; Email: sonsam72@yahoo.co.uk; Address: UNICEF-KIMS proposals, Kalinga Institute of Medical Sciences, Campus-5, Patia, Bhubaneswar-24, India.

Published by Sciedu Press 


\section{INTRODUCTION}

The global burden of malnutrition under five children figures are staggering, that is, 178 million (one third of all children) are stunted, 112 million are underweight \& 55 million are wasted and to add to this 13 million children are born each year with intrauterine growth retardation. Together, this is considered to be the precipitating cause of $21 \%$ of all under five deaths. ${ }^{[1]}$ In the causal matrix of under nutrition, an important underlying determinant is care provided to the child. There is increasing awareness that cultural and behavioral practices with regard to child rearing practices influence child nutrition. The key care practices that could impact on child nutrition include care of pregnant and lactating mothers, breast feeding and feeding young children, care of children during illness, psychosocial care of children, food preparation and storage, hygiene and the programmatic or political environment of the place of residence. ${ }^{[2]}$ This has a tremendous impact on a developing country, like India, with a high burden of disease and low access to safe water and sanitation. Even in developed countries, recent studies have underscored the role of Infant Young Child Feeding (IYCF) practices in reducing child mortality. ${ }^{[3,4]}$

The World Health Organization (WHO) recommends exclusive breastfeeding for the first six months of life with early initiation and continuation of breastfeeding for two years or more together with nutritionally-adequate, safe, ageappropriate complementary feeding starting at six months. ${ }^{[5]}$ The WHO and United Nations Children Fund (UNICEF) have articulated a global strategy for infant- and young childfeeding. Based on these guiding principles, the Government of India, in collaboration with international agencies, has adopted the culturally-acceptable IYCF guidelines, which were incorporated in the Integrated Management of Neonatal and Childhood Illness (IMNCI) Programme ${ }^{[6]}$ that is being implemented across the country.

The current status of feeding practices in India that promote child growth as cited by the National Family Health Survey3 (2005-2006) is rather dismal. Early initiation of breast feeding is reported in about a third of births, prelacteal feeds are administered in over half the infants and exclusive breast feeding in infants less than six months is a little under 50 per cent. Data with respect to complimentary feeding suggest that about 50-60 per cent children have timely introduction of complimentary foods but good feeding practices are reported in just about 50 per cent of children at 12-24 months of age. ${ }^{[7]}$ The National Family Health Survey (NFHS-3) has provided useful national- and state-level information on the IYCF practices. ${ }^{[8]}$ Available data showed a gross inter-state variation. However, the NFHS was not designed to provide district-level data.
This clearly hints that unless massive improvements in child nutrition are made, it will be difficult to achieve the Millennium Development Goal 4: Reduce child mortality by 2015.

Odisha, the state where the study was carried out is one of the low performing states of India with an Infant Mortality Rate of 51 per 1,000 live births against the national average of 40 . (SRS 2013) The state is fast developing and committed to improve its health indicators given a very favorable political and programmatic environment. However the challenges are that the state houses nearly $5 \%$ of the marginalized population in the country that stay in very remote areas and have little access to the specialized health services, which are limited to the cities or towns. The state has administrative units called districts and the District Health Surveys (DHS) which are done annually; give a fair picture of the health status of the districts. The DHS 2013 for Odisha has shown that the districts with tribal and vulnerable population have scored poorly in case of child health indicators. These populations have their firm cultural practices and are very resistant to outer influences. Hence there was a need to undertake a baseline survey to study the prevailing IYCF practices and understand the gaps in knowledge and services delivery. This survey was also used as an opportunity to have an icebreaking session with the villages and convince them that the state administration wished for their upliftment.

\section{Aims \& OBJECTIVES}

With this background Odisha Voluntary Health Association (OVHA) implemented a project SURAKHYA- Promotion of Infant $\&$ young child feeding Practice in Odisha covering all 30 Districts with 314 Blocks and 1,570 Gram Panchayat \& 9,420 villages in March 2011 with active support of UNICEF, Bhubaneswar branch. To improve the implementation and conceive cost effective district specific strategies it was envisaged to perform a baseline survey in 7 of the emphasis districts which were categorized as the Intensive Implementation(II) districts namely Deogarh, Angul, Dhenkanal, Sundergarh, Gajapati, Koraput, Nuapada. The objectives of the study were:

(1) To calculate the CORE indicators of IYCFP for the II districts.

(2) To calculate any 2 of the optional indicators for the II districts.

(3) To get supportive sociodemographic \& maternal child health programmatic information in the designated districts. 


\section{Material \& Methods}

underlined.

The baseline survey intends to provide proportions at the project level and was carried out with the design detailed as
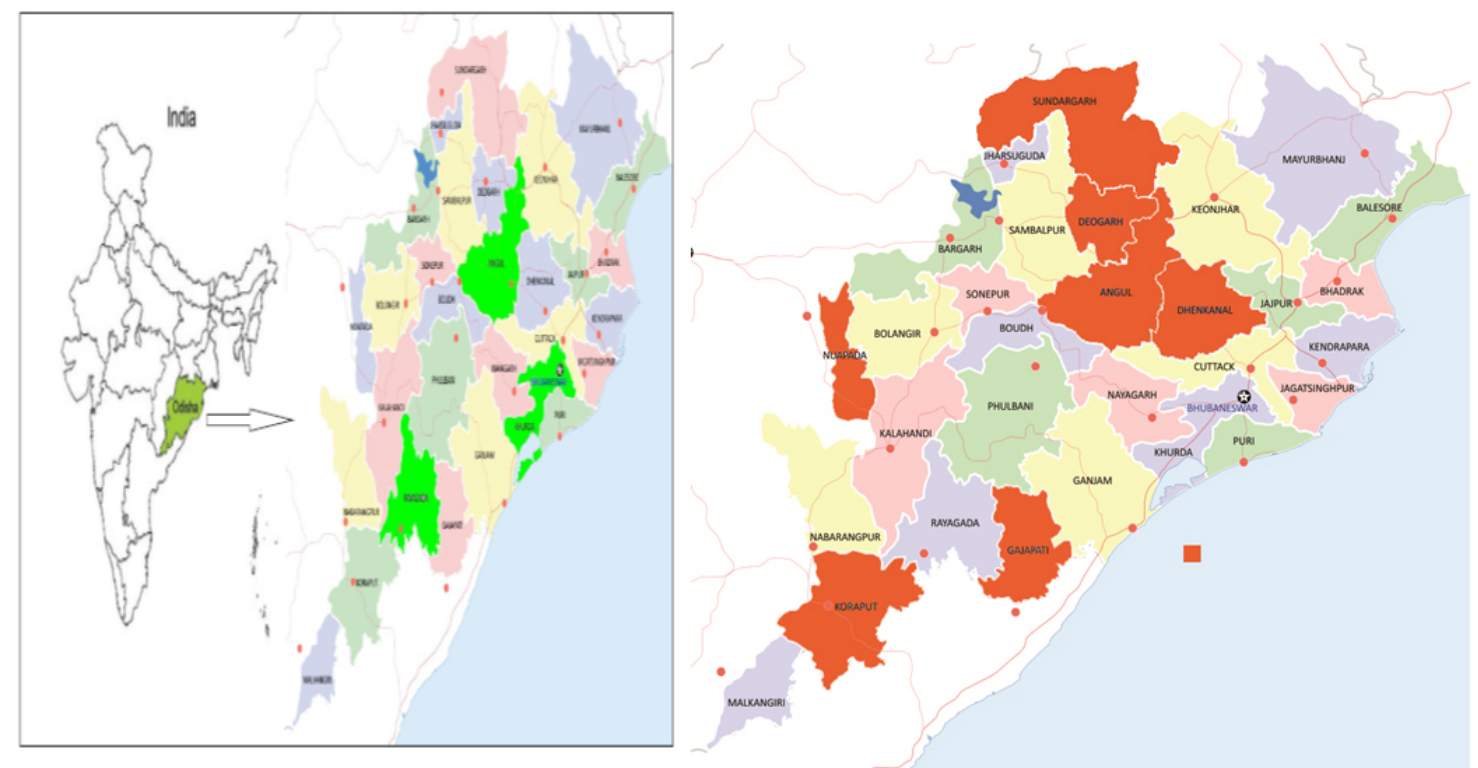

Figure 1. Map of Odisha as a part of the country India and the sampled districts indicated in red

A multi stage sampling methodology was conducted to first get sampled villages as the primary stage units (PSU) and there from households within the selected villages as the ultimate stage units (USU). A district is an administrative unit within a state in India which is further divided into blocks and then into villages. Each village has a minimum of a thousand population and has the smallest unit of health care delivery in the country.

A total of 60 villages were selected from the 7 intervention districts using the list of villages as per Census 2001. Selection of these villages was done using Probability Proportion to Size (PPS) sampling. The list was finalized after due consultation with the UNICEF \& District level officials, excluding the naxalite affected (some of the villages are affected by local terrorist activity and hence declared unsafe for travel) and inaccessible regions.

To ensure adequate inclusion of the marginalized population, it was decided that listing of the households would precede the survey. It would require at least 300 households to be listed for getting adequate number of sample households being envisaged for the survey. One village, a part of a village, or a combination of villages were selected, going by the list so as to be as close to the desired segment size of 300 households. For very large villages (households $\geq$ 400), segmentation was done and a segment having about 300 households was listed. For small villages (households $\leq$
250), it was needed to include an adjacent village to arrive at the segment of 300 households.

While listing, households having infant (0-5 months) and children in the age group of 6 to 23 months were identified. In each selected village, 6 and 12 households respectively were selected randomly from the stratum of households having infant (0-5 months) and children in the age group of 6 to 23 months. The listing activity preceded the actual survey by 5-7 days and was ensured that there is no further delay in the initiation of the study so as to avoid the spilling of the 5 months aged infants into the 6-23 months category. A survey team was hired for the listing and survey data collection activity which was duly trained for 2 days on all the predefined activities. A pretested predesigned and locally modified survey questionnaire was prepared as per the Manual on Indicators for assessing infant and young child feeding practices Part 3 Country Profiles. ${ }^{[9]}$

Separate detailed questionnaires were developed for $0-5$ months age group and for 6-23 months age group. The respondents were the mothers of the sampled children after informed consent of the head of the household as well as the mother herself. Help was sought from the local village health guides, who are called ANMs (Auxiliary Nurse Midwives) in the Indian health system in order to facilitate the smooth working out of the survey. Besides questions to assess the core indicators of infant feeding practices, there 
were questions that would elicit information on sociodemographic profile, care givers attitude, feeding practices, assess to other Mother and Child Health related state run initiatives and finally on hygiene, hand washing, disease and disposal of child feces.

Thus the final sample size was calculated as:

Minimum expected coverage of infants (0-5 months): 60 villages $\times 6$ households $=360$

Minimum expected coverage of children (6-23 months): 60 villages $\times 12$ households $=720$

Total: 1,080 households.

Operational definitions that were used in survey were as per WHO guidelines and the core and optional indicators are as per the WHO document. ${ }^{[9]}$

\section{Core indicators:}

- Exclusive breast feeding (infants 4-5months): Proportion of infants 4-5 months of age who are fed exclusively with breast milk

- Early initiation of breast feeding: Proportion of children born in last 24 months who were put to the breast within one hour of birth

- Continued breast feeding at one year: Proportion of children 12-15 months of age who are fed breast milk

- Minimum Dietary Diversity: Proportion of children 6-24 months of age who receive foods from 4 or more diverse groups

- Minimum Meal Frequency: proportion of breastfed and non breastfed children 6-23 months of age, who receive solid, semi-solid or soft foods (but also including milk feeds for non breastfed children) the minimum number of times or more

\section{Optional indicators:}

- Children ever breast fed: Proportion of children born in last 24 months who were ever breastfed

- Continued breastfeeding at 2 years: Proportion of children 20-23 months of age who are fed breast milk

- Bottle Feeding: Proportion of children 0-23 months of age who are fed with a bottle

The duration of listing and survey were for 3 months ie from July 15th to Oct 15th 2011. Data was entered in CSPro 4.1for double entry, cleaned and subsequently analysed on SPSS version 7.5 for the final results and inferences. Percentages and chi-sqaure were used for statistical analysis and interpreting the results.

\section{Results}

Table 1 shows that in the current sample, $89.3 \%$ of the respondents were Hindus and among the Hindus over $95 \%$ were SC/ST/OBC by caste. These caste divides and tribes among Hindus in India had been traditionally designed to delegate work and these people over the years have been neglected and marginalized, inspite of several governmental strategies for their upliftment. Nearly $75 \%$ of the mothers were between 20-29 years of age. Male/female ratio was nearly $4: 5$. Out of the total, $40.6 \%$ of the respondent mothers had no formal education and another $8 \%$ were educated till class 4 and $77 \%$ were housewives.

Table 1. General Sociodemographic profile of the Respondents

\begin{tabular}{|c|c|c|c|}
\hline Parameters & Total & Parameters & Total \\
\hline Religion Hindu & $89.3 \%$ & $\begin{array}{l}\text { Education of } \\
\text { mother }\end{array}$ & \\
\hline Muslim & $1.0 \%$ & $\begin{array}{l}\text { No formal } \\
\text { education }\end{array}$ & $40.6 \%$ \\
\hline Christian & $9.6 \%$ & Upto $4^{\text {th }}$ & $8.2 \%$ \\
\hline Caste Hindus n=963 & & $5^{\text {th }}$ to $8^{\text {th }}$ class & $20.3 \%$ \\
\hline General & $4.3 \%$ & $9^{\text {th }}$ to $10^{\text {th }}$ class & $23.8 \%$ \\
\hline Scheduled Caste(SC) & $18.9 \%$ & $11^{\text {th }}-12^{\text {th }}$ class & $3.9 \%$ \\
\hline Scheduled Tribe(ST) & $37.1 \%$ & $\begin{array}{l}\text { Graduation or } \\
\text { more }\end{array}$ & $3.2 \%$ \\
\hline $\begin{array}{l}\text { Other Backward Caste } \\
(\mathrm{OBC})\end{array}$ & $39.8 \%$ & $\begin{array}{l}\text { Mother's } \\
\text { occupation }\end{array}$ & \\
\hline $\begin{array}{l}\text { Age of mother(in } \\
\text { years) }\end{array}$ & & Household work & $77.2 \%$ \\
\hline $18-20$ & $16.1 \%$ & Labourer & $19.3 \%$ \\
\hline $21-30$ & $75 \%$ & Employed & $3.5 \%$ \\
\hline $31-40$ & $8.4 \%$ & & \\
\hline$>40$ & $0.3 \%$ & & \\
\hline $\begin{array}{l}\text { Age of the child(in } \\
\text { months) }\end{array}$ & & $\begin{array}{l}\text { Socioeconomic } \\
\text { status } N=1,042\end{array}$ & \\
\hline $0-6$ & $390(36.2)$ & Kutcha & $54.6 \%$ \\
\hline $7-12$ & 284(26.3) & Semi-pucca & $26.4 \%$ \\
\hline $13-23$ & $404(37.5)$ & Pucca & $20.2 \%$ \\
\hline Gender of child & & $\begin{array}{l}\text { Access to } \\
\text { electricity }\end{array}$ & $72.9 \%$ \\
\hline Male & $48.2 \%$ & Landholding & $63.2 \%$ \\
\hline Female & $51.8 \%$ & $\begin{array}{l}\text { Open field } \\
\text { defecation }\end{array}$ & $75.8 \%$ \\
\hline
\end{tabular}

The socioeconomic conditions as can be opined out of the data are poor as nearly $54.6 \%$ of self owned houses were katcha meaning thereby that the roof, floor and walls were made temporary materials like mud, tree materials and only $20 \%$ had pucca houses ie permanent strong building materials were used. Only $73 \%$ had access to electricity and $63 \%$ owned their own lands for agricultural purposes and nearly $25 \%$ had inbuilt toilet facilities in house compelling the rest 
to go for open field defecation, a practice very common in rural India.

Table 2 findings elucidate that the exclusive breast feeding in the $0-5$ months sample was seen to be $48.1 \%$. Koraput reports $76.4 \%$ closely followed by Nuapada at $62.5 \%$. Least was reported in this age group at Deogarh \& Dhenkanal i.e. $30 \%$ and $31 \%$ respectively. The trend of exclusive breast feeding declined in 4-5 months below $40 \%$ in most of the sampled districts with the exemption of Koraput and Nuapada. The trends in EBF were seen to be better than the National average of $24.8 \%$.

Table 2. Exclusive breast feeding practices in intervention districts

\begin{tabular}{|c|c|c|c|c|c|c|c|c|c|}
\hline \multirow{2}{*}{$\begin{array}{l}\text { Core indicator } \\
1\end{array}$} & \multicolumn{7}{|c|}{ District } & \multirow[b]{2}{*}{ Total (360) } & \multirow[b]{2}{*}{ AHS 2010-11 } \\
\hline & $\begin{array}{l}\text { Dhenkanal } \\
\text { (42) }\end{array}$ & $\begin{array}{l}\text { Angul } \\
\text { (66) }\end{array}$ & $\begin{array}{l}\text { Deogarh } \\
\text { (30) }\end{array}$ & $\begin{array}{l}\text { Sundargarh } \\
\text { (66) }\end{array}$ & $\begin{array}{l}\text { Gajapati } \\
\text { (60) }\end{array}$ & $\begin{array}{l}\text { Koraput } \\
\text { (72) }\end{array}$ & $\begin{array}{l}\text { Nuapada } \\
\text { (24) }\end{array}$ & & \\
\hline $\begin{array}{l}\text { Exclusive breast } \\
\text { feeding ( } 0-5 \\
\text { months) }\end{array}$ & $31.0 \%$ & $40.9 \%$ & $30.0 \%$ & $39.4 \%$ & $46.7 \%$ & $76.4 \%$ & $62.5 \%$ & $48.1 \%$ & $24.8 \%$ \\
\hline EB (4-5 months) & $.0 \%$ & $21.1 \%$ & $.0 \%$ & $28.6 \%$ & $29.4 \%$ & $75.0 \%$ & $42.9 \%$ & $34.3 \%$ & - \\
\hline
\end{tabular}

This hints that contrary to the popular belief that marginalized populations breast feed their baby, the practice being cost effective, it is observed that there are districts in Odisha where it is even below $50 \%$ and the decline is more alarming in 4-5 months age group across the sample.
Table 3 describes the practice of other core indicators in the sample population district wise. Early initiation of breast feeding is reported in only $45.5 \%$ of the total sample, highest being in Gajapati \& Koraput and least in Deogarh. Continuation of breast feeding after 1 year was well reported in all districts i.e. above $98 \%$.

Table 3. Other core IYCF indicators in the sampled districts

\begin{tabular}{|c|c|c|c|c|c|c|c|c|c|}
\hline \multirow{2}{*}{$\begin{array}{l}\text { Indicat } \\
\text { or No. }\end{array}$} & \multirow{2}{*}{$\begin{array}{l}\text { Indicators } \\
\text { (yes to the } \\
\text { indicator) }\end{array}$} & \multicolumn{7}{|c|}{ District } & \multirow{2}{*}{$\begin{array}{l}\text { Project estimate } \\
\text { /Comparisons } \\
\text { with state figures }\end{array}$} \\
\hline & & Dhenkanal & Angul & Deogarh & Sundargarh & Gajapati & Koraput & Nuapada & \\
\hline 2 & $\begin{array}{l}\text { Early initiation } \\
\text { of breast feeding } \\
(\mathrm{n}=490)\end{array}$ & $37.3 \%$ & $48.5 \%$ & $31.1 \%$ & $37.4 \%$ & $56.2 \%$ & $51.9 \%$ & $45.8 \%$ & $\begin{array}{l}\text { 45.5\% } \\
54.3(\text { NFHS-3) } \\
54.9 \%(\text { DHLS-3) }\end{array}$ \\
\hline 3 & $\begin{array}{l}\text { Continued } \\
\text { breast feeding } \\
\text { after one year } \\
(\mathrm{n}=204)\end{array}$ & $100.0 \%$ & $97.4 \%$ & $100.0 \%$ & $97.2 \%$ & $100.0 \%$ & $100.0 \%$ & $93.8 \%$ & $\begin{array}{l}98.6 \% \\
\text { No state figures }\end{array}$ \\
\hline 4 & $\begin{array}{l}\text { Minimum } \\
\text { Dietary } \\
\text { Diversity } \\
(\mathrm{n}=191 / 696)\end{array}$ & $22.2 \%$ & $27.3 \%$ & $25.4 \%$ & $31.5 \%$ & $25.4 \%$ & $29.9 \%$ & $25.5 \%$ & $\begin{array}{l}27.4 \% \\
\text { No state figures }\end{array}$ \\
\hline 5 & $\begin{array}{l}\text { Minimum meal } \\
\text { frequency } \\
(n=209 / 696)\end{array}$ & $22.6 \%$ & $29.5 \%$ & $18.3 \%$ & $34.8 \%$ & $22.0 \%$ & $39.6 \%$ & $22.9 \%$ & $\begin{array}{l}29.1 \% \\
\text { No state figures }\end{array}$ \\
\hline
\end{tabular}

The indicators minimum dietary diversity where the children 6-23 months of age who receive 4 or more food groups comes to be only $27.4 \%$ in the selected sample. The minimum meal frequency, which as per the definition is getting at least 4 or more meals a day, was noted to be only $29 \%$ in the given sample. This probably brings out the fact that all the benefit that the children gained by EBF and continued breast feeding was negated by lack of appropriate complimentary feeding and explains the high wasting and stunting seen in the coun- try in under five children. Thus this strongly brings out the necessity to strengthen the ongoing home nutrition supplementation schemes that have been outlaid by the government in all the districts.

Table 4 depicts the optional breast feeding practices area wise. In the survey sample, children ever breast fed and continued breast feeding after 2 years was nearly $99.6 \%$ and $89 \%$ respectively. Use of bottle feeding (which is currently banned by Indian Association of Pediatrics) was also noted 
in $13.5 \%$ of fewer than 2 years children which was similar to less than a month \& $30 \%$ of them between $3-4$ months. the findings reported by the National survey. Nearly $21 \%$ of the total bottles fed infants were put on the bottle at an age

Table 4. Optional Breast feeding indicators

\begin{tabular}{|c|c|c|c|c|c|c|c|c|c|c|}
\hline \multirow{2}{*}{$\begin{array}{l}\text { Indicat } \\
\text { or No. }\end{array}$} & \multirow{2}{*}{ Indicators } & \multicolumn{7}{|c|}{ District } & \multirow{2}{*}{ Total } & \multirow[b]{2}{*}{ NFHS-3 } \\
\hline & & Dhenkanal & Angul & Deogarh & Sundargarh & Gajapati & Koraput & Nuapada & & \\
\hline 1 & $\begin{array}{l}\text { Children ever } \\
\text { breastfed } \\
(n=1,024)\end{array}$ & $100.0 \%$ & $99.0 \%$ & $100.0 \%$ & $99.5 \%$ & $100.0 \%$ & $99.5 \%$ & $100.0 \%$ & $99.6 \%$ & $94.7 \%$ \\
\hline 2 & $\begin{array}{l}\text { Continued breast } \\
\text { feeding after two } \\
\text { years }(n=100)\end{array}$ & $88.2 \%$ & $83.3 \%$ & $100.0 \%$ & $88.9 \%$ & $86.7 \%$ & $94.1 \%$ & $100.0 \%$ & $89.3 \%$ & - \\
\hline 3 & $\begin{array}{l}\text { Bottle feeding of } \\
\text { infants }(n=146)\end{array}$ & $23.0 \%$ & $12.6 \%$ & $20.0 \%$ & $15.2 \%$ & $14.6 \%$ & $6.5 \%$ & $5.6 \%$ & $13.5 \%$ & $5 \%-18 \%$ \\
\hline
\end{tabular}

In the above tables, chi-square test (Yates correction applied) indicates that EBF practice is definitely higher in the marginalized groups, in case of institutional delivered babies and where mother's education is better.

Table 5 indicates that EBF practice is definitely higher in the marginalized groups, in case of institutional delivered babies and where mother's education is better.

Table 5. Associations between the social conditions and feeding practices

\begin{tabular}{|c|c|c|c|}
\hline Parameters & EBF-Yes & EBF- No & Associations \\
\hline Caste Gen & $21(6.6 \%)$ & $06(3.8 \%)$ & \\
\hline SC & $55(17.2 \%)$ & $26(16.7 \%)$ & \\
\hline ST & 125(39.2\%) & $75(48.1 \%)$ & $P<.05$ \\
\hline $\begin{array}{l}\text { Delivery } \\
\text { Institutional }\end{array}$ & $153(42.5 \%)$ & 124(34.4\%) & \\
\hline Home & $49(13.6 \%)$ & $34(9.4 \%)$ & $P<.022$ \\
\hline $\begin{array}{l}\text { Mother's education } \\
\text { Illiterate }\end{array}$ & 98 & 54 & \\
\hline Upto $4^{\text {th }}$ & 14 & 09 & \\
\hline $5-8^{\text {th }}$ class & 42 & 31 & \\
\hline $9-10^{\text {th }}$ class & 62 & 25 & \\
\hline $11-12^{\text {th }}$ class & 07 & 05 & \\
\hline Graduate and above & 08 & 05 & $P<.000$ \\
\hline
\end{tabular}

The advocacy of practice of EBF was prioritized in this study as out of the total infants deaths reported in the state maximum are the early neonate group and probably this safe and cost-effective method can work marvels in curbing the unfortunate trend.

The gender, visits by Health Nurse, place of delivery and age of the mother was not found to affect the infant feeding practices significantly in this study. Since the population was mostly marginalized the socio-economic conditions of the sample were almost similar and were not found to be significantly associated with the feeding practices.

\section{DISCUSSION AND SALIENT FEATURES}

The project estimates of the sample indicate that the breast feeding practices need much more attention in the state of Odisha. The practice of EBF in this study is $48.1 \%$ which is close to the Orissa figure of NFHS 3(2005-2006) i.e. 50.3\% and thus we see a dip in the practice. The study reveals the district specific variations and in some districts like Dhenkanal and Deogarh it is as low as $30 \%$. Thus, contrary to the popular perception that the practice is very high among the marginalized populations, the program managers should be more realistic and explore sternly into the reasons of this dipping trend. Similar study done in neighboring state West Bengal in 2010 reported EBF at $57.1 \%{ }^{[10]}$ which though is better is also short of the 10th plan target of the country of $80 \% .{ }^{[11]}$ Similar findings were observed by Saha et al. in Bangladesh ${ }^{[12]}$ and Hop et al. in Viet $\mathrm{Nam}^{[13]}$ in longitudinal studies. Studies in India with historic recall noted that about one-fourth of study children received exclusive breastfeeding for six months. ${ }^{[14,15]}$ The reasons cited in this study for the decline in exclusive breast feeding, especially in the latter months is that Odisha being a coastal region experiences extremely hot and humid climate all through the year and hence the mothers out of concern give water to their infants, and thus violate the mandate of exclusive breast feeding. This finding is to be taken up by the health providers and advocacy should be done for EBF, as even scientifically it has been proved that removal of water from the child feeds can improve EBF rates by $15 \%$. In our study mothers education is seen to have a favorable association with practice of EBF. 
The early initiation of breast feeding is reported to be $45.5 \%$ as against $13.6 \%$ reported in West Bengal study ${ }^{[10]}$ and very close to the National 10th plan target of 50\%. ${ }^{[11]}$ A study in Ghana reported that $22 \%$ of all neonatal deaths could be prevented if all women could initiate breastfeeding within one hour of delivery. ${ }^{[16]}$ An epidemiological evidence of a causal association between early initiation of breastfeeding and infection-specific neonatal mortality has also been documented. ${ }^{[17]}$

The indicators calculated for 6-23 months age group were of greater concern as minimum dietary diversity is reported $27.4 \%$ and minimum meal frequency is $29 \%$. Very few studies have explored these components which qualify the complimentary feeding to be appropriate for age. These inputs are also absent in the National surveys undertaken. The West Bengal study ${ }^{[10]}$ also noted far worse figures ie appropriate feeding as per the IMNCI protocol was significantly less among infants aged 6-11 months at $15.2 \%$ and children aged $12-23$ months at $8.7 \%$. Female education has been reported to influence complementary feeding patterns in children in Bangladesh study ${ }^{[18]}$ while in our study no significant association could be found as the number of women educated above senior secondary education was only $7 \%$ $8 \%$. In Odisha, there is a strong effort is being made by the Health Managers to offer supplementary nutrition to post natal women and children from 6-23 months of age in the form of fortified ration. However the actual benefit drawn from these nutritional schemes need to be evaluated as is hinted from this study.

Our study brings out that women seeking institutional delivery services have better feeding practices which certainly reinforces the role of health providers in propagating these appropriate feeding practices in the community.

Thus this study strongly hints at consolidation of infant feeding practices across the state of Odisha. Contrary to our belief that breast feeding is a popular and widely practiced cultural practice, and thus we take it for granted that our EBF is very high, the figures reveal a grim picture. This poses a challenge for the current project Surakhsya to intensify the intervention strategies for the IYCFP in the districts of Odisha especially in the Intervention districts. Revitalization of the Baby Friendly Hospital Initiative in health facilities is recommended. Region specific programmes, keeping in mind the composition of the population with regards to their religion and cultural practices and health needs are to be planned to create an enabling environment for comprehensive nutrition and health education of mothers/care-givers, health and nutrition workers to protect, promote, and sustain the optimal IYCF practices across the country.

\section{REFERENCES}

[1] Black RE, Allen LH, Bhutta ZA, et al. Maternal and child undernutrition: global and regional exposures and health consequences. Lancet. 2008; 371: 243-60. http://dx.doi.org/10.1016/S0140-673 6(07) 61690-0

[2] Arimond M, Ruel MT. Assessing care: Progress towards the measurement of selected childcare and feeding practices, and implications for programs. Washington DC: Food and Nutrition Technical Assistance Project, Academy for Educational Development; 2002.

[3] Chen A, Rogan WJ. Breastfeeding and the risk of post neonatal death in the United States. Pediatrics. 2004; 113: e 435-9.

[4] Quigley MA, Kelly YJ, Sacker A. Breastfeeding and hospitalization for diarrheal and respiratory infection in the United Kingdom Millennium Cohort Study. Pediatrics. 2007; 119: e837-42. PMid:17403827. http://dx.doi.org/10.1542/peds. 2006-2256

[5] World Health Organization Global strategy for infant and young child feeding. Geneva: World Health Organization; 2003. p. 41.

[6] India Ministry of Health and Family Welfare. Integrated management of neonatal and childhood illness. Training module of health workers. New Delhi: Ministry of Health and Family Welfare, Government of India; 2003. pp. 74-5.

[7] National Family Health Survey 2005-2006 (NFHS-3). Mumbai: International Institute of Population Sciences. Available from: http: //www.nfhsindia.org

[8] International Institute for Population Sciences National family health survey (NFHS 3), 2005-06: India. V. I. Mumbai: International Institute for Population Sciences; 2007. p. 540.

[9] WHO/UNICEF/IFPRI/UCDavis/FANTA/AED/USAID. Indicators for assessing infant and young child feeding practices. Part 1: Definitions. Geneva, World Health Organization, 2008.

[10] Sinhababu A, Dipta K. Mukhopadhyay et al .Infant- and Young Childfeeding Practices in Bankura District, West Bengal, India. J Health Popul Nutr. 2010 Jun; 28(3): 294-9.

[11] Planning Commission of India. Tenth five year plan (2002-2007). V. 2. New Delhi: Government of India; 2001. Chapter 3; p. 337.

[12] Saha KK, Frongillo EA, Alam DS, et al. Appropriate infant feeding practices result in better growth of infants and young children in rural Bangladesh. Am J Clin Nutr. 2008; 87: 1852-9. PMid: 18541577.

[13] Hop LT, Gross R, Giay T, et al. Premature complementary feeding is associated with poorer growth of Vietnamese children. J Nutr. 2000; 130: 2683-90. PMid:11053507.

[14] Roy S, Dasgupta A, Pal B. Feeding practices of children in an urban slum of Kolkata. Indian J Community Med. 2009; 34: 362-3. PMid:20165637. http://dx.doi.org/10.4103/0970-0218.58 402

[15] Kumar D, Goel NK, Mittal PC, et al. Influence of infant-feeding practices on nutritional status of under-five children. Indian J Pediatr. 2006; 73: 417-21. PMid:16741328. http://dx.doi.org/10.10 07/BF02758565

[16] Edmond KM, Zandoh C, Quigley MA, et al. Delayed breastfeeding initiation increases risk of neonatal mortality. Pediatrics. 2006; 117 e380-6. PMid:16510618.

[17] Edmond KM, Kirkwood BR, Amenga-Etegos S, et al. Effect of early infant feeding practices on infection-specific neonatal mortality: an 
investigation of the causal links with observational data from rural Ghana. Am J Clin Nutr. 2007; 86: 1126-31. PMid:17921392.

[18] Mihrshahi S1, Kabir I, Roy SK, et al. South Asia Infant Feeding
Research Network. Determinants of infant and young child feeding practices in Bangladesh: secondary data analysis of Demographic and Health Survey 2004: Food Nutr Bull. 2010 Jun; 31(2): 295-313. PMid:20707235. 